\title{
Pembelajaran Problem Solving Dalam Mengembangkan Psikomotorik Anak Usia Dini di Era Revolusi 4.0
}

\author{
Mitra Binariang Lase, ${ }^{* 1}$, Yuliati Siantajani, ${ }^{2}$ Desetina Harefa ${ }^{3}$ \\ Prodi PAK, STT Real Batam \\ Prodi PAK, STT Real Batam \\ Prodi PK-AUD, STT Real Batam \\ mitralase97@gmail.com
}

\begin{abstract}
This research starts from the problems that are seen in the Paud Paris Karya Baru Palembang school, where there are some early children who do not experience psychomotor development, because the learning applied is still passive. The author observes this happening because learning is done more centered on teacher educators. Therefore it is very much needed a learning model that includes students in the learning process, so that students are more active in developing their skills and abilities in learning in the current 4.0 revolution era. So in writing this thesis, the writer formulates the problem as follows: first, What are the forms or forms of development of the psychomotor domain of early childhood through learning problem solving in the era of the industrial revolution 4.0. after the research data is collected, the writer processes and analyzes finding out the form of problem solving learning so that it can develop the psychomotor domain of early childhood. To find the answer, the authors adjusted the field observation data with the literature review data, with a simple analysis using descriptive methods using qualitative research through classroom action research. After everything has been analyzed, the writer can finally conclude that problem solving learning is able to develop the psychomotor domain of early childhood in the industrial revolution era 4.0.
\end{abstract}

Keywords: Problem Solving, Psychomotor, Early Childhood, Revolutionary Era 4.0

\begin{abstract}
Abstrak
Penelitian ini bertitik-tolak dari masalah-masalah yang terlihat di sekolah Paud Paris Karya Baru Palembang, dimana ada beberapa anak usia dini yang tidak mengalami perkembangan psikomotorik, dikarenakan pembelajaran yang diterapkan masih bersifat pasif . Penulis mengamati hal tersebut terjadi dikarenakan pembelajaran yang dilakukan lebih banyak berpusat pada guru pendidik. Oleh sebab itu sangat diperlukan model pembelajaran yang mengikut sertakan siswa dalam proses pembelajaran, sehingga peserta didik lebih aktif mengembangkan keterampilan dan kemampuanya dalam belajar di era revolusi 4.0 saat ini. Sehingga dalam penulisan skripsi ini, penulis merumuskan masalah sebagai berikut: Apa saja wujud atau bentuk dari pengembangan psikomotorik anak usia dini lewat pembelajaran problem solving di era revolusi industri 4.0. Setelah data-data penelitian terkumpul, penulis mengolah dan menganalisa mencari tahu wujud dari pembelajaran problem solving sehingga dapat mengembangkan ranah psikomotorik anak usia dini. Untuk menemukan jawabannya, penulis menyesuaikan data observasi lapangan dengan data literature review, dengan analisa sederhana yaitu menggunakan metode deskriptif dengan menggunakan penelitian kualitatif melalui penelitian tindakan kelas. Setelah semuanya itu dianalisa maka akhirnya bisa penulis simpulkan bahwa pembelajaran problem solving mampu mengembangkan psikomotorik anak usia dini di era revolusi industri 4.0.

Kata Kunci : Problem Solving, Psikomotorik, Anak Usia Dini, Era Revolusi 4.0.
\end{abstract}




\section{PENDAHULUAN}

Perkembangan psikomotorik merupakan suatu proses atau usaha untuk meningkatkan kemampuan/ keterampilan seseorang sebagai jawaban dalam bentuk gerakan melibatkan fisik yang didapat dari hasil pendidikan, yang sangat penting dan bermanfaat bagi kehidupan manusia. Hal ini dapat dilatih sejak pendidikan usia dini dan akan terus berlanjut selama proses pertumbuhan hingga beranjak dewasa. Pendidikan anak usia dini dapat diartikan sebagai sarana yang sangat fundamental dalam membentuk pondasi terbentuk dan berkembangnya dasar-dasar pengetahuan, sikap dan keterampilan pada anak. ${ }^{1}$

Pengembangan psikomotorik anak usia dini merupakan hal yang wajib untuk dilakukan di era perkembangan zaman saat ini. Dapat dilihat bahwa anak-anak hanya tahu pakai peralatan untuk bermain, alat tulis dan lain sebagainya dari hasil karya oranglain untuk belajar tanpa menghasilkan karyanya sendiri supaya dipergunakan saat bermain dan belajar atau pada saat melakukan kegiatan lainya. Sekalipun kenyataannya bahwa siswa memiliki keterampilan yang perlu dikembangkan, akan tetapi karena kebanyakkan proses belajar di sekolah tidak terlalu fokus untuk mengembangkan keterampilan maka peserta didik pada masa usia dini tahunya super instan atau semua serba tersedia tanpa melihat bahwa alam disekitar bisa dipergunakan untuk menciptakan teknologi sederhana atau sesuatu hal yang baru yang dapat digunakan untuk belajar maupun bermain.

Pengajaran yang dilakukan pendidik hanya terfokus pada pengajarkan abjad dan perhitungan sehingga terkesan pasif dan membuat peserta didik tersebut tidak berkembang dibidang keahlian lain. Proses pembelajaran di sekolah sangat mempengaruhi perkembangan anak itu sendiri.

Pendidikan adalah hal yang sangat penting untuk manusia karena dapat menciptakan manusia yang berkualitas, berintelektual dan jauh dari kebodohan. ${ }^{2}$ Untuk mewujudkan manusia yang benar-benar berkualitas dalam perkembangan zaman harus dimulai sejak manusia tersebut memperoleh pendidikan pada masa usia dini. Karena pada masa usia dinilah manusia mudah dibentuk dan dipersiapkan menjadi manusia yang cerdas dan kreatif. Akan tetapi kebanyakan pendidikan di sekolah tidak memperhatikan hal tersebut, dimana sekolah menggunakan model-model pembelajaran yang lebih banyak waktu untuk mengembangkan pengetahuan tanpa memerhatikan bahwa anak didik pada masa usia dini sangatlah perlu mempersiapkan menjadi pribadi yang terampil dan mampu menciptakan, menghasilkan atau menemukan teknologi terbaru sesuai dengan kemampuan anak itu sendiri.

Pada masa usia dini anak seharusnya sudah mulai memiliki kreativitas dan karyakarya tertentu yang dibuat sendiri seperti membuat mobil mainan dari botol aqua bekas, membuat prakarya gantungan kunci dari beragam bahan bekas seperti kardus, kain perca,

\footnotetext{
${ }^{1}$ Mursid, Pengembangan Pembelajaran PAUD (Bandung: PT Remaja Rosdakaraya, 2015).Hal.4

${ }^{2}$ Hamid Darmadi, Sulha, and Ahmad Jamalong, Pengantar Pendidikan (Bandung: Alfabeta, 2018).64
} 
botol plastik dan membuat kupu-kupu dari kertas origami, sudah bisa menari atau senam, melukis, berlari, melompat dan lain sebagainya. Peserta didik memiliki kemampuan yang luar biasa walau sederhana namun sebenarnya hal ini menjadi dasar keuntungan besar untuk dikembangkan dengan cara-cara yang baru.

Dalam perkembangan zaman dan teknologi sangat diharapkan pendidikan yang baik untuk semua siswa khususnya pada masa usia dini supaya lebih mengfokuskan bagaimana cara mengembangkan keterampilan anak di masa usia yang masih mudah untuk diajar dan dibentuk. Salah satu yang menjadi alternatif untuk mengatasi permasalahan di atas adalah menggunakan metode pembelajaran yang sudah ada namun belum pernah diterapkan. Dalam pemilihan metode pembelajaran harus disesuaikan, karena metode pembelajaran tersebutlah nantinya yang akan menjawab setiap permasalahan siswa. Penulis melihat masalah yang dialami oleh peserta didik tersebut mengarah kearah kurangnya berkembang di ranah psikomotorik. Oleh sebab itu, metode pembelajaran yang akan digunakan harus menyenangkan, efektif, aktif serta melibatkan fisik siswa yang tidak hanya mental saja, suatu metode pembelajaran yang mengajak siswa untuk ikut serta aktif dalam pembelajaran.

Penulis melihat salah satu metode pembelajaran yang menyenangkan, efektif dan aktif adalah metode pembelajaran problem solving karena metode pembelajaran problem solving dapat melibatkan siswa untuk berpikir, memberikan kesempatan pada siswa untuk mengaplikasikan pengetahuan yang mereka miliki dalam dunia nyata dan dapat mengembangkan sikap keterampilan siswa dalam memecahkan permasalahan, serta dalam mengambil keputusan secara objektif dan mandiri. Pada pembelajaran problem solving ini menggunakan metode lain juga untuk mewujudkan suatu tujuan. Oleh karena itu anakanak harus dipersiapkan dengan baik untuk menghadapi perkembangan zaman, dengan tujuan agar generasi ini mempunyai mental yang kuat, keberanian, mandiri, kreatif dan tidak bergantung sepenuhnya kepada orangtua, guru dan orang lain. Dunia terus berubah, pendidikan juga harus berubah. Jika dilihat anak-anak di zaman tahun seribuan sangat berbeda dengan anak zaman sekarang khususnya di era revolusi industri 4.0 yang lebih banyak waktu dengan teknologi.

\section{METODE}

Dalam makalah ini penulis menggunakan pendekatan kualitatif melalui Penelitian Tindakan Kelas (PTK). Teknik analisis data dilakukan dengan cara observasi, wawancara/interviem, dan dokumentasi pada kegiatan aktivitas belajar di dalam kelas.

\section{HASIL DAN PEMBAHASAN}

\section{Pembelajaran Problem Solving Sebagai Metode Pembelajaran Di Kelas}

Pembelajaran Problem Solving merupakan pembelajaran yang merangsang cara berpikir siswa. Proses belajar mengajar dengan menggunakan pemecahan masalah. Karena melalui pendekatan ini ibaratnya siswa tidak langsung diberikan ikan, tetapi diberi kail, 
yakni alat untuk memperoleh ikan agar anak mengetahui bahwa ikan tidak datang dengan sendirinya melainkan harus butuh usaha untuk memancing di laut atau di sungai. Dengan begitu, siswa memahami benar masalah yang terjadi dan dapat memecahkan melalui proses yang tidak instan. Siswa akan lebih aktif dan ikut serta dalam proses pembelajaran pada pemecahan masalah yang sedang dibahas.

Masalah tidak terlepas dalam kehidupan sehari-hari, baik seorang pendidik, anak didik dan lain sebagainya. Dalam hal ini yang terpenting adalah bagaimana cara individu tersebut menyelesaikan masalah yang ada dengan cara-cara yang benar. Masalah mempunyai manfaat dalam perkembangan manusia. seperti yang dikatakan Erikson dalam jurnal Patnani, bahwa disetiap tahap perkembangan manusia pasti diperhadapkan yang namanya krisis. Erikson juga mengemukakan setiap manusia yang berhasil dalam menyelesaikan krisis tersebut, maka pada akhirnya akan memberikan waktu dan kesempatan kepada individu untuk berkembang jika dihadapi atau diselesaikan dengan benar. $^{3}$

Demikian halnyalah yang terjadi di dalam pembelajaran kelas, topik pembelajaran di ibaratkan sebagai masalah yang belum diketahui mau jadi apa, oleh sebab itu diperlukan proses yang benar untuk dapat menyelesaikan dengan baik lewat pembelajaran problem solving, hal tersebut yang akan dilakukan oleh peserta didik di kelas maupun juga di luar kelas yang tidak terlepas dari pantauan pendidik sehingga peserta didik terbiasa terampil dan bisa memecahkan masalah sendiri, baik di lingkungan sekolah, di rumah maupun dimana saja siswa tersebut berada.

\section{Perkembangan Psikomotorik Anak Usia Dini}

Pendidikan sekarang yang berada ditingkat PAUD sudah diperhadapkan dengan bagaimana cara untuk mengupayakan anak didik mengetahui dan mengenal berbagai keterampilan yang menunjukkan kepada anak didik dan dapat dipahami secara tepat kegunaan dan fungsinya sejak dini.

\section{Keterampilan Sekolah}

Jika anak dilatih sejak usia dini lewat pembelajaran yang mengikut sertakan siswa dalam proses belajar, maka secara tidak sadar peserta didik diberi kesempatan untuk aktif dan bisa dengan bebas mengepresikan bakat yang ada pada diri anak tersebut. Anak didik mengalami perkembangan dalam dirinya untuk mengenal setiap perlengkapan sekolahnya dan begitu juga dengan fungsi serta kegunaannya.

Peserta didik yang berusia 3-5 tahun lebih mudah menangkap kalimat yang memberi kesan seperti kalimat yang berbentuk panjang, pendek, lurus maupun bengkok. Secara tidak langsung anak mulai merespon kalimat tersebut dengan menuangkannya dalam selembar kertas bahkan bisa jadi di dinding rumah, dengan plastisin serta di dinding

\footnotetext{
${ }^{3}$ Patnani, “Upaya Meningkatkan Problem Solving Pada Mahasiswa,” Jurnal Psikogenesis 1 (2013).Hal.3
} 
sekolah, dilantai maupun di atas pasir dengan menuliskan hurus-huruf sekalipun bukan dalam bentuk kata-kata konvensional, karena bagi anak-anak itu sudah menjadi kata atau kalimat, hal tersebut sangat perlu dikembangan dan dihargai. Peserta didik juga bisa membedakannya dalam bentuk-bentuk alat perlengkapan belajar yang ada di sekolah. Keterbiasaan untuk mandiri sejak kecil akan menjadi ekspetasi untuk saat ini dan juga untuk masa depan dalam menciptakan karya-karya yang baru khususnya dalam perkembangan zaman di era revolusi 4.0.

Demikian pula anak didik ketika diberikan pensil warna dan buku gambar, maka anak dengan sendirinya mulai berpikir dan langsung bertindak untuk menggunakan peralatan tersebut sesuka hatinya. Maka akan terlihat keterampilan anak didik dari hasil yang dilakukan, diumur usia dini kemungkinan hanya bisa mencoret-coret dan memenuhi kertas dengan gambar dan karya yg masih kurang jelas. Sekalipun dari hasil tidak memuaskan namun hal tersebut sangat bermanfaat untuk dikembangan yang berguna untuk dimasa yang akan datang dan tidak terlepas dalam pantauan seorang guru dalam mendidik dan mengembangkan psikomotorik anak lewat proses pembelajaran yang tidak pasif.

\section{Keterampilan Bermain}

Untuk mengembangkan lingkungan yang nyaman bagi anak-anak khususnya anak yang masih usia dini, sangat perlu untuk melatih dan mengembangkan kemampuannya untuk menciptakan atau keterampilan yang baru melalui proses pembelajaran yang aktif dan kreatif.

Fadlillah mengatakan dalam bukunya bahwa bermain merupakan suatu hal yang paling baik dan tidak bisa terlepas dari dunia anak-anak maupun dalam proses pembelajaran karena sangat mempengaruhi untuk perkembangan anak, hal inipun merupakan suatu cara belajar anak yang efektif. ${ }^{4}$ Oleh karena itu anak dapat mengembangkan keterampilannya dan kreafitasnya melalui bermain. Pendapat Ahmad Susanto dalam bukunya tentang keterampilan anak untuk bermain dikatakan, bahwa anak itu harus terus diberi kesempatan untuk bermain sendiri karena dengan bermain anak dapat mengembangkan ide-idenya dan cara anak tersebut berpikir tentang dirinya sendiri tanpa ditemani oleh orang lain. Sedangkan menurut Brunner dalam buku Maykes S. Tedjasaputra dikatakan bahwa bermain merupakan sangat berkaitan dengan naratif dengan cara seseorang atau anak untuk mengepresentasikan ilmu yang didapat dalam bentuk intensionalitas dan kesadarannya. ${ }^{5}$

Salah satu kemajuan anak atau perkembangan anak dapat dilihat dari kemampuannya untuk bermain dan menggunakan alat-alat mainan yang ada dan bahkan menciptakan alat-alat mainan dari bahan-bahan alam agar dijadikan sebagai alat permainan untuk digunakan secara pribadi maupun secara bersama-sama.

\footnotetext{
${ }^{4}$ M.Fadlilah, Buku Ajar Bermain \& Permainan Anak Usia Dini (Jakarta: Prenadamedia, 2019).Hal. 1

${ }^{5}$ Maykes S. Tedjasaputra, Bermain, Mainan Dan Permainan (Jakarta: Grasindo, 2001). Hal.11
} 
Secara psikologi perkembangan keterampilan anak (psikomotorik) anak yang berusia 3-5 tahun sudah mampu secara spontan berinteraksi dengan orang lain dan bermain dengan baik dan benar tanpa merugikan orang lain dalam arti pada saat bermain, mainan tersebut tidak digunakan untuk melukai kawan atau menggunakannya dengan hal-hal yang lain. Benda-benda yang berada disekitarnya dipergunakan dengan sangat senang dan gembira serta memiliki inisisatif sendiri menggunakan daya khayalnya, memakai seluruh panca inderanya dan seluruh anggota tubuhnya untuk bermain.

\section{Keterampilan Menolong Diri Sendiri}

Euis Sunanarti dan Rulli purwanni mengatakan bahwa keterampilan anak dalam menolong diri sendiri diasosiasikan dengan keterampilan fisik dan gerak anak, artinya segala sesuatu yang diperlukan oleh anak didik untuk mampu menjalani hidupnya sesuai dengan tuntutan lingkungan dimana anak didik berada. ${ }^{6}$ Keterampilan menolong diri sendiri dapat membantu peserta didik dalam menjalani hidupnya setiap hari, baik ketika berada di rumah, di sekolah maupun pada saat berada di tengah-tengah masyarakat, hal ini dapat dilihat dari kemampuan dasarnya melakukan sesuatu seperti memegang pulpen dengan benar, makan sendiri, mandi, dapat memasang dan melepas pakaian yang ditarik ke atas, dapat menalikan tali sepatu sendiri, mengenakan kaos kaki sendiri, hingga mampu membuat tali sepatu sendiri dan lain sebagainya.

Di era revolusi 4.0 hal-hal diatas sangat menjadi pondasi yang kuat untuk membuat anak mandiri dan mampu menghadapi perkembangan zaman karena sudah melakukan kebiasaan-kebiasaan yang berguna untuk dirinya sendiri yang merupakan keterampilan dasar anak-anak, keterampilan tersebut dapat menolong anak didik untuk bisa mandiri tanpa harus bergantung sepenuhnya kepada guru maupun orangtua di rumah. Resiko ketika anak tidak memiliki keterampilan menolong dirinya sendiri maka anak tersebut akan tidak mengalami perkembangan dan secara psikologi tidak sehat, oleh sebab itu orang tua dan guru harus memiliki kerjasama untuk mengembangkan keterampilan anak untuk menolong dirinya sendiri terlebih dahulu.

\section{Keterampilan Menolong Orang Lain}

Menolong orang lain adalah hal yang sangat baik dan bernilai tinggi bagi mata manusia maupun di mata Tuhan. Perilaku seperti itulah yang diinginkan bagi setiap pribadi manusia, perilaku tersebut akan timbul ketika seseorang menyadari betapa pentinya hidup bersosial. Untuk anak usia dini sangat penting memiliki keterampilan untuk menolong orang lain karena hal tersebut merupakan nilai-nilai yang terpuji.

Dalam perkembangan zaman saat ini menolong orang lain atau sesama harus lebih ditingkatkan dan dikembangkan supaya rasa persaudaraan lebih terlihat sekalipun dalam

\footnotetext{
${ }^{6}$ Euis Sunarti and Rulli Purwanni, Ajarkan Anak Keterampilan Sejak Dini (Jakarta: Elex Media Komputindo, 2005). Hal.23
} 
dunia yang sudah dikuasai dengan teknologi yang canggih, dan hal ini sangat baik ketika dikembangkan sejak anak usia dini. Salah satu sikap menolong orang lain ialah berbagi

Seperti yang dikatakan oleh Andi Agusniatih dan Jane M Manopa dalam bukunya bahwa menolong orang lain adalah salah satu usaha atau kemampuan menunjukkan sikap bersimpati kepada orang lain, salah satunya mengibur teman saat sedang bersedih. ${ }^{7}$ Melepaskan sesama dari kesedihan sudah menjadi salah satu bagian menolongnya untuk tidak berlarut-larut dalam kesedihan sehingga pada saat seorang kawan mengiburnya, dapat bersukacita kembali. Contohnya anak didik yang menghibur temannya pada saat atau sedang bersedih karena ditinggal sama orang tua tanpa ditemani untuk belajar. Kemudian yang menjadi salah satu bagian dari keterampilan menolong orang lain ialah ketika anak mau berbagi sesuatu kepada teman yang sedang membutuhkan pertolongan seperti teman yang ketinggalan pensil dan lain sebagainya, dan juga mau berbagi makanan kepada teman yang tidak membawa bekal dari rumahnya masing-masing.

Penulis menyimpulkan bahwa keterampilan dalam menolong orang lain adalah saah satu tindakan yang sangat berharga yang tidak dapat diukur oleh apapun, karena dapat dilihat dari perkembangan zaman saat ini yang semakin sibuk dengan kesibukan masingmasing tanpa memandang sekeliling bagi mereka yang membutuhkan bantuan dan pertolongan. Sangat penting untuk dibekali sejak masa kecil lewat proses pembelajaran yang membuat peserta didik mandiri dan ikut serta dalam belajar yang tidak kaku, sehingga nilai-nilai tersebut menjadi kebiasan dan dapat tertanam sampai masa tua yang akan datang dan tidak memiliki sikap yang egois atau mementingkan diri sendiri sekalipun berada di era yang semakin modern.

\section{KESIMPULAN}

Problem solving merupakan pembelajaran yang diterapkan dalam mengembangkan keterampilan anak di usia dini. Karena pembelajaran problem solving adalam pembelajaran yang merangsang cara berpikir siswa. Proses belajar mengajar dengan menggunakan pemecah masalah. Malalui pembelajaran ini ibaratnya siswa tidak langsung dikasi ikan melainkan diberi kail, yakni alat untung memperoleh ikan agar anak mengetahui bahwa ikan tidak datang dengan sendirinya melainan butuh usaha untuk memancingnya. Dengan begitu, siswa akan lebih aktif dan ikut serta dalam proses pembelajaran pada pemecahan masalah yang sedang dibahas. Pembelajaran problem solving dapat membantu siswa dalam memecahkan masalah, dapat menemukan pengetahuan baru, meningkatkan kreativitas peserta didik, mengetahui cara mentransfer pengetahuan dalam dunia nyata dan dapat membantu siswa untuk mengembangkan pengetahuan baru yang diperoleh.

\footnotetext{
${ }^{7}$ Andi Agusniatih and Jane M Manopa, Keterampilan Sosial Anak Usia Dini: Teori Dan Metode Pengembangan (Jawa barat: Edu Publisher, 2019). Hal.31
} 
Perkembangan psikomotorik pada anak usia dini dalam pembelajaran problem solving di era revolusi 4.0 adalah perkembangan dalam belajar di sekolah, perkembangan keterampilannya dalam bermain, menolong diri sendiri dan orang lain.

\section{KEPUSTAKAAN}

Agusniatih, Andi, and Jane M Manopa. Keterampilan Sosial Anak Usia Dini: Teori Dan Metode Pengembangan. Jawa barat: Edu Publisher, 2019.

Darmadi, Hamid, Sulha, and Ahmad Jamalong. Pengantar Pendidikan. Bandung: Alfabeta, 2018.

M.Fadlilah. Buku Ajar Bermain \& Permainan Anak Usia Dini. Jakarta: Prenadamedia, 2019.

Mursid. Pengembangan Pembelajaran PAUD. Bandung: PT Remaja Rosdakaraya, 2015. Patnani. “Upaya Meningkatkan Problem Solving Pada Mahasiswa.” Jurnal Psikogenesis 1 (2013).

Sunarti, Euis, and Rulli Purwanni. Ajarkan Anak Keterampilan Sejak Dini. Jakarta: Elex Media Komputindo, 2005.

Tedjasaputra, Maykes S. Bermain, Mainan Dan Permainan. Jakarta: Grasindo, 2001. 